\title{
Nienapisana epopeja. Kilka uwag o zapomnianym wyzwoleniu
}

Andrzej Leder 


\section{Nienapisana epopeja. Kilka uwag o zapomnianym wyzwoleniu}

Andrzej Leder

TEKSTY DRUGIE 2017, NR 6, S. 54-67

DOI: $10.18318 /$ td.2017.6.4

Ta olbrzymia, dokonana w cieniu praca pojawia się na powrót w snach, cieniach i decyzjach, zwłaszcza w okresach ważnych przemian i zaburzeń społecznych; stanowi ona wielką wspólną skarbnicę dla wszystkich ludów i jednostek. Najskuteczniej aktywizuje ją - niby gorączka - rewolucja i wojna.

Doktor Pierre Mabille

\section{I}

Mówi się czasem, że ulubionym gatunkiem XIX-wiecznej niemieckiej powieści mieszczańskiej był Bildungsroman. Podmiot wędrował, w czasie i przestrzeni, by ze stanu niedojrzałości wejść w kondycję samostanowienia. Mnie w Polsce brakuje opowieści - a właściwie całego cyklu, serii, zbioru powieści, czy też filmów, obrazów emancypacji. Znaków emancypacji. Tej emancypacji znaczących.

Jeśli mówię o emancypacji znakach, czy z n a c zą c y c h, to dlatego, że wydaje mi się niewystarczający fakt,

\section{Andrzej Leder -}

doktor habilitowany, profesor w Instytucie Filozofii i Socjologii PAN. Autor rozpraw: Nieświadomość jako pustka. Wokół myśli Freuda i Husserla, Nauka Freuda wepoce 'Sein und Zeit', Prześniona rewolucja, ćwiczenie z logiki historycznej, Rysa na tafli. Teoria w polu psychoanalitycznym i The Changing Guise of Myths. Naucza w Szkole Nauk Społecznych IFiS PAN i w Collegium Civitas. 
że mamy kilka powieści, opracowań czy seriali, zwykle znanych akademikom, a odnoszących się do tego tematu. Te teksty kultury nie funkcjonują w zbiorowym dyskursie, nie zamieniają się w scenariusze, organizujące zbiorową wyobraźnię. Nie są z n a c z ą c y m i, w takim sensie, że nie organizują samoreprezentacji podmiotu. Nie rządzą tym, jak sam się postrzega.

Żeby bowiem teksty kultury mogły stać się - w sensie Lacanowskim z n a c z ą c y $\mathrm{m}$ i, musiałyby ustanawiać samoreprezentację zbiorowego podmiotu. Musiałyby pozwalać mu na wędrowanie przez wyobrażenie własnych dziejów. Pozwalać na przemierzanie trajektorii, na której z n a c z ą c e są jakby drogowskazami, pozwalającymi zachować kierunek ruchu. Te fantazmatyczne trajektorie, szkielet wyobrażeń o własnej tożsamości, tworzone są w przekazie rodzinnego domu, potem szkoły, przywoływane w trakcie nieskończonych obchodów, świąt państwowych, uroczystości, przepowiadane w ich trakcie przez miliony ust, ponownie dyskutowane w programach publicystycznych i popularyzujących, obrazowane na afiszach zdobiących mury miast, ale też w graffiti czy w „memach" pojawiających się w nieskończonych odsłonach portali społecznościowych...

Dziś zresztą tekst nieuchronnie musiałby się zamienić w obrazy - choćby filmowe - musiałby nasycić elementy przepełniające przestrzeń widzialności, musiałby odzwierciedlić się w nazwach ulic i świąt, wreszcie skoncentrować się w miejscach pamięci, choćby monumentach czy muzeach stawianych w kluczowych punktach przestrzeni zapamiętywania.

Oczywiście w Polsce istnieje narracja, organizująca samoreprezentację podmiotu. To epopeja ludu szlacheckiego, opowiadająca jego dzieje. Od dominacji na ogromnych przestrzeniach międzymorza w I Rzeczypospolitej, przez utratę tej pozycji wraz z rozbiorami, szarpaninę tłumionych przez wojska rosyjskie i tonących w obojętności ludu chłopskiego powstańczych zrywów, odzyskaną II Rzeczpospolitą z hegemonią inteligencko-wojskowo-urzędniczej kasty, po okupację niemiecką i rosyjską z zamordowanym powstaniem warszawskim jako ukoronowaniem owej epopei. I wreszcie ambiwalentną epokę PRL.

To epopeja martyrologiczna. Nie jest to jednak epopeja emancypacyjna.

A przecież ostatnie sto pięćdziesiąt lat to czas historii wielkiego ruchu, przemieszania stanów, upodmiotowienia poddanych, poniżenia możnych, ukonstytuowania się mieszczaństwa. Gdzie to wszystko? Gdzie więc opowieść, znaki tej opowieści, w naszej wspólnej świadomości?

Dodatkową trudność stwarza tu konieczność przedstawienia społecznego ruchu. Nie chodzi bowiem o zilustrowanie takiej czy innej formy bytowania 
chłopskiego; zachowanych gdzieś do dzisiaj form autentycznej kultury ludowej czy zapisanych u dawnych etnologów obyczajów i gwar włościańskich. Nie chodzi też o socjologiczne opracowanie Pamiętników chtopów, choć ono, w porównaniu do innych tekstów, na pewno o wiele wyraźniej rejestruje pękanie skorupy społeczeństwa stanowego w międzywojennej Polsce. Nie chodzi wreszcie o genezę klasy robotniczej, z jej wzlotem i upadkiem. Chodzi o coś innego, o przedstawienie potężnego strumienia emancypacji, spersonifikowanie tego powolnego, ale niepowstrzymanego wyrywania się ze zniewolenia społecznego, materialnego, politycznego, mentalnego wreszcie. Ukazanie całej ambiwalencji, przemieszania wzniosłości i małostkowości, okrucieństwa i rozmachu, które tej epopei towarzyszyły. Obdarzenie twarzą jej anonimowych do dzisiaj bohaterów.

Czy takie przedstawienie jest możliwe? Czy można uchwycić dziejowy proces jako bohatera epopei?

W eseju Legenda miasta-potwora Czesław Miłosz tak właśnie pisze o komedii ludzkiej Balzaca. Proces rodzenia się społeczeństwa kapitalistycznego w XIX-wiecznym Paryżu ujęty jest przez metaforę miasta - potwornego organizmu. Nie chodzi jednak tylko o naturalizację rzeczywistości społecznej, chodzi o uchwycenie procesu nieustannej transformacji, rozpuszczania wszelkich tożsamości - indywidualnych i zbiorowych - w tyglu buzującego społeczeństwa nowoczesności. Pisze Miłosz: „Tam, gdzie mieszają się warstwy, gdzie wciąż nowe siły napływają z nizin i na odwrót, dawni oligarchowie spadają do rzędów proletariatu, gdzie wciąż muszą przyswajać nowe twarze, a ich obraz przysłania twarze przyjaciół, dzieli przyjaciół dziś widzianych od tych samych widzianych przedwczoraj - tam zrozumiały jest pęd do transformizmu i zainteresowanie transformizmem"1.

W Polsce nie ma jednak takiej „komedii ludzkiej”, nie ma nawet czegoś porównywalnego do cyklu filmów Woody'ego Allena, opowiadających o kondycji zglobalizowanego mieszczaństwa drugiej połowy XX wieku, niezależnie od tego, czy mieszka w Nowym Jorku, Londynie czy Barcelonie. Jest tylko Lalka Bolesława Prusa i Ziemia obiecana Reymonta. Niezależnie od pazura tych dzieł to za mało. Za dawno. Zbyt statycznie.

Literatura współczesna, zagłębiająca się w autoreferencyjne gry z podmiotem, narracją i formą, nie jest epopejami zainteresowana. Ości Ignacego Karpowicza, przykład pisarstwa tego okresu, nie pozwalają na sfalsyfikowanie tezy Marcela Reicha-Ranickiego, że literatura polska po przełomie 1989 roku

1 C. Miłosz Legendy nowoczesności, Wydawnictwo Literackie, Kraków 1996, s. 21. 
nie potrafiła opowiedzieć o formowaniu się nowego społeczeństwa. Choć potrafi zręcznie podsuwać mu krzywe zwierciadło.

Może więc wcześniej, zanim mogłaby pojawić się literatura, historia emancypacji właśnie jako ruchu, niepowstrzymanego strumienia płynącego wraz z okolicznościami historycznymi, a często przeciw nim, musiałaby się stać przedmiotem pracy historyków. I to nie tych zajmujących się historią polityczną "narodu szlacheckiego", wraz z jego sejmami, powstaniami i podziemnymi państwami, ale przede wszystkim badaczy historii społecznej. Nie obawiających się pokazania tego, jak kultura hegemoniczna, przepojona katolicyzmem kultura szlachty, ziemiaństwa i dużej części inteligencji, była w permanentnym konflikcie z potężnym społecznym nurtem emancypacji. Potrzebna więc byłaby też praca historyków zajmujących się przemianami mentalności i kultury, wrażliwych na ten właśnie konflikt i gotowych ślady tego konfliktu w artefaktach kulturowych odczytywać. Piszących historię w zgodzie z tezą Waltera Benjamina: „Nie istnieje dokument kultury, który nie byłby zarazem dokumentem barbarzyństwa. I tak jak on sam nie jest wolny od barbarzyństwa, naznaczony barbarzyństwem jest także proces jego przekazu, w wyniku którego przechodził z rąk do rąk. W miarę możliwości materialista historyczny stara się więc od tej tradycji zdystansować. Swoje zadanie upatruje w czesaniu historii pod włos"2.

Jak wielu takich historyków jest dzisiaj w Polsce? Nic dziwnego, że pracę za nich wykonuje Francuz, Daniel Beauvois ${ }^{3}$.

\section{II}

Zacznijmy więc od uwłaszczenia w Królestwie Polskim. Zacznijmy od tego wydarzenia choćby dlatego, że ukaz cara Aleksandra II z 2 marca 1864 roku, uwłaszczający chłopów w Królestwie, następuje bardzo niedługo po podobnym wydarzeniu po drugiej stronie Atlantyku, Akcie Emancypacyjnym Abrahama Lincolna z 1 stycznia 1863. Można więc szukać interesujących paralel. Na przykład takiej: oba wydane zostały w trakcie wojny prowadzonej przeciw lokalnemu „ziemiaństwu” - polskiej szlachcie w Królestwie i południowym plantatorom w USA. Swoim zasięgiem obejmowały właśnie zbuntowane

2 W. Benjamin O pojęciu historii, przeł. A. Lipszyc, A. Wołkowicz, w: tegoż Konstelacje. Wybór tekstów, Wydawnictwo Uniwersytetu Jagiellońskiego, Kraków 2012, s. 315.

3 D. Beauvois Trójkq̨t ukraiński. Szlachta, carat i lud na Wołyniu, Podolu i Kijowszczyźnie 1793-1914, Wydawnictwo UMCS, Lublin 2011. 
ziemie. Oba też spotkały się z zajadłym, skrytym oporem dawnych „właścicieli niewolników". Ten opór do dzisiaj kształtuje - tu i tam - imaginarium pokonanych społeczności.

Czy więc obok tkwiącego w pamięci powstania styczniowego - nieszczęścia narodu szlacheckiego - przedmiotem nowej historycznej epopei mogłoby być wyzwolenie chłopów? Mimo że akt ów wymierzony był w powstańczą szlachtę, polski historyk musiałby zmierzyć się z tym, że wolność zawsze jest wspaniała. Nawet jeśli przynosi ją car północy. Zgodnie z wydanym przez Aleksandra II dekretem właściciele ziemscy nie mieli już prawa „dysponować" chłopami, karać ich czy przesiedlać. Chłopi zaś mogli nabywać ziemię na własność, mieli też otrzymywać nadziały gruntowe za część nominalnej ich wartości i na wieloletnie raty.

Czy ktoś w Polsce myśli dziś o tym, co to właściwie znaczyło, że wcześniej właściciele ziemscy mieli prawo „dysponować chłopami”, karać ich czy przesiedlać? Że jeszcze zupełnie niedawno jeden człowiek mógł w majestacie prawa pobić drugiego? Bo go „karał”. Albo że człowiek mógł się dowiedzieć o utracie domu, dobytku, rodzinnego miejsca, bo został przesiedlony, dobrze jeśli z rodziną? Czy doczekamy się Quentina Tarantino, który opowie we współczesny sposób zwyczajną brutalność, wypędzanie, głód? I to, że odwołać się można było, owszem, do sądu dominialnego. Pańskiego. Czyli sądu, w którym sądził ten sam, który przed chwilą bił, wyzyskiwał, wypędzał. Albo jego plenipotent. Kto współodczuwał, może poza Leonem Kruczkowskim, z upokorzeniem, które z tym się wiązało? I zajadłą, bezsilną wściekłością, która musiała się w ludziach gromadzić? Wściekłością, która do dzisiaj buzuje w Polakach.

Więc gdy nagle nikt tymi ludźmi nie mógł już „dysponować”, to musiała być nieprawdopodobna zmiana w mentalności, sposobie odczuwania, stosunkach. Brak mi jednak obrazu pierwszego pokolenia wolności. Tego, które wiedziało jeszcze, do czego służą dyby, ale już mogło samo decydować o swoim losie. Zastanawiam się, czy jego nastawienia nie wyrażają słowa cytowane przez Józefa Chałasińskiego: „Pan musi być, będziesz pokorny, zarobisz i łaski zaznasz. Podobnie i wojsku. Co byłoby bez pana, cham by ci rozkazywał, a sameś chamem i nic mądrego by nie było. Bóg już tak stworzył i tak musi być. To przedwieczny porządek stały. Nie wolno go psuć. Naród za pańszczyzny był lepszy, posłuszniejszy" ‘? Czy to uwewnętrznione poddaństwo, fakt, że 
właśnie wyobrażenie pańskiej wspaniałości opromieniało nędzę chłopskiego bytowania, tłumaczy jakoś brak buntów chłopskich na tym obszarze Rzeczypospolitej, na którym dominował katolicyzm? Bo przecież rabacja galicyjska jest raczej wyjątkiem niż regułą. Apologeci sarmatyzmu będą tłumaczyć to zjawisko zapewne idyllicznymi stosunkami panującymi w folwarku. Uderzające jest jednak to, że buntów nie było też na niewolniczym Południu Stanów Zjednoczonych. Może więc chodzi raczej o skalę zniewolenia. O pozbawienie poddanych nawet takich zasobów mentalnych, jakie ruscy chłopi wschodu Rzeczypospolitej - regularnie się buntujący - znajdowali w prawosławiu i tradycji kozackiej? Może trzeba by się przyjrzeć roli kontrreformacyjnego Kościoła polskiego? Bo zastanawiająca jest skala rebelii na ziemiach ruskich i martwa cisza - w Polsce etnicznej.

Kiedy więc i w jaki sposób ta mentalność się zmieniła? W jaki sposób pierwsze pokolenia po uwłaszczeniu wrastały w indywidualną podmiotowość, konieczną, by móc gospodarzyć na swoim? Jak w ciągu trzydziestu pięciu mniej więcej lat, które oddzielały carski ukaz od końca wieku, ukształtowały się stosunki, opisane przez Reymonta w Chtopach?

Kluczowe jest tu prawo do nabywania gruntów. Car obiecał nadania szlacheckiej ziemi za ułamek wartości, ale to się nie stało. Co wiemy o historii ziemiańskiego oporu przeciw parcelacji? Czy pamiętamy o tym, komu udawało się wykręcić, zatrzymać zmiany, uniknąć? Nie powstańczym bohaterom; bo tym, dalibóg, rosyjskie władze nie odpuszczały. Komu więc i jak udało się doprowadzić do tego, że raptem osiem procent ziemi pańskiej zostało podzielone? Polskie źródła historyczne, ogólnie niezbyt wylewne w opisach wszystkiego, co z reformami agrarnymi związane, akcentują zwykle moment dobrych intencji kolejnych polskich inicjatorów reform. Tadeusz Kościuszko z uniwersałem połanieckim, „czerwoni” w Powstaniu Styczniowym... Tyle dobrych chęci i zawsze z tak marnym skutkiem. Źródła milczą o zaciętym oporze większości ziemian, o łapówkach, balach dla carskich urzędników, kupczeniu córkami, wydawanymi za „kogoś wpływowego" - wszystko, byle wykręcić się od podziału ziemi...

Skąd więc wiemy, że tak było? A jak mogło być inaczej? To kwestia logiki, nie historii. Historii w tym miejscu brak.

Trochę więcej wiemy o nędzy z tym ziemiańskim oporem związanej, o tworzeniu się stosunków na wsi, sportretowanych potem przez Reymonta. Tak, dzięki jego chłopskiej powieści możemy sobie wyobrazić bezwzględność życia uwarunkowanego głodem ziemi. Ale jednocześnie powieść ta jest zawieszona w bezczasie, jakby przemianie historycznej wyrwano w niej zęby. 
Jak stara fotografia, na której odnajdujemy twarze uśmiechnięte albo zrozpaczone, choć nie wiemy, co właściwie stało się między sportretowanymi ludźmi, saga Reymonta stanowi cięcie przez nurt czasu, ujawniające strukturę, ale zapominające o genealogii. Dlatego pewnie mogła zasłużyć na noblowską nagrodę w Norwegii, odnajdującej w niej uniwersalne cechy chłopskiego, surowego bytowania. „Poddańcza” geneza opisanych przez Reymonta stosunków, geneza zupełnie inna niż w Skandynawii, gdzie chłopska wolność miała już wtedy wiele wieków historii, pozostaje w Chtopach prawie zupełnie skryta.

Czy ktoś więc w Polsce upamiętnił pierwszy moment wolności? Carskie władze wiedziały, że trzeba upamiętniać. A uzyskały w tym wsparcie ogromnej rzeszy chłopskich darczyńców, którzy złożyli się na pomnik Aleksandra II w Częstochowie. Czemu zapomniana jest ta historia? Może nie czemu, a po to, by nie przemyśleć napisów: Wybudowany w 1889 przez wiejska społeczność Królestwa Polskiego i Dekret 19 lutego 1864 - niech ten dzień zostanie na wieczna pamięć chtopom Królestwa jako dzień ponownego ich dobrobytu. Bo inicjatywa zaborczej administracji uzyskała masowe wsparcie „włościan”. Może więc owo „aktywne zapominanie” przez polską kulturę hegemoniczną wdzięczności, którą wiejski lud obdarzał Rosyjskiego Cara, pogromcę patriotów, jest symptomatyczne dla niechęci do myślenia o tym, dla kogo dobra miała być cała XIX-wieczna walka o niepodległość, a kto tej niepodległości mógł się bać?

W historii tego pomnika materiał dramatyczny jest znakomity. Wystarczyłoby choćby opowiedzieć taką oto intrygę: podjętą przez jakichś nieudaczników próbę wysadzenia tego monumentu w 1904 roku i wreszcie zburzenie go - oczywiście przez skutecznych Niemców - w 1917.

Podobnie fascynujące mogłoby być opowiedzenie historii uwłaszczenia galicyjskiego. Wystarczyłoby „zobrazować” zbiór dokumentów, wydany przez profesora Kieniewicza pod tytułem Rewolucja polska $1846^{5}$. Od powstania krakowskiego i rabacji 1846, przez stłumienie ruchów chłopskich przez Austriaków, po Wiosnę Ludów i dekret gubernatora Franciszka Stadiona z 22 kwietnia o uwłaszczeniu „w imieniu cesarza”.

Zatem wioski, niektóre, to doceniały. Na Roztoczu Wschodnim, wówczas części Galicji, stawiały z bruśnieńskiego kamienia krzyże wolności'. Tworząc coś, co mogło stać się miejscem pamięci, a okazało się skamienieliną

5 Rewolucja polska 1846 roku. Wybór źródeł, oprac. S. Kieniewicz, Zakład Narodowy im. Ossolińskich, Wrocław 1950.

6 Korzystam z niepublikowanego artykułu Macieja Piotrowskiego Zapomniane pomniki wolności. O pamiq̨tkach zniesienia pańszczyzny z bruśnieńskiego ośrodka kamieniarskiego. 
zapomnienia. Bloki albo krzyże, stojące często do dzisiaj w najznaczniejszych miejscach wsi, zarosły mchem. Nie da się odczytać napisów, wykuwanych na nich tuż po uwłaszczeniu, jak ten w Hucie Różanieckiej, na pamiątkę „UWOLNIE/NIA NAS/OD PAŃ/SZCZY-/ZNY/PRZEZ NAJ/JAŚNIEJSZEGO/ MONARCHĘ/FERDYNAN/DA") ${ }^{7}$. Słowa zostały zachlapane wapnem. Czy znamy opowieść o tych kamieniach, o ich stawianiu, o przeżyciach z nimi związanych? O zapomnieniu? O dumie pierwszego pokolenia, uwolnionego, i wstydzie następnych, nie chcących pamiętać o upodleniu ojców. O społecznej genezie galicyjskiej nędzy i chocholego tańca, sportretowanego w Weselu?

\section{III}

Częstochowa, Sosnowiec, Łódź. Po zniesieniu niewolnictwa czarni w Ameryce poszli do miast Północy, takich jak Chicago czy Detroit. Gdzie poszli polscy chłopi? Przemysł rozwijał się w kilku ośrodkach Kongresówki, potężnie, żywiołowo. Mamy na szczęście Ziemię obiecana, w której wyczuwalne jest szczególnie w przetworzeniu Wajdy - owo pulsowanie bestii, rodzącego się kapitalizmu, który wciąga i wynosi w nową epokę rzesze ludzi, stających się proletariatem; przed chwilą wychodźców z głodnych, chłopskich wsi albo małych, żydowskich miasteczek. A może, mimo istnienia tych kilku miast przemysłowych, jednak w większości nie mieli dokąd pójść? I skazani byli na narastającą, wzajemną nienawiść, kulminującą w pogromach?

Ziemia obiecana to zresztą jedyny chyba tekst polskiej kultury, oddający owo pulsowanie potwora; to, co Marks uchwycił w znanych słowach: „Ciągły przewrót w produkcji, bezustanne wstrząsanie wszystkimi stosunkami społecznymi, wieczna niepewność i wieczny ruch - wyróżniają epokę burżuazyjną spośród wszystkich innych"8. Nie jawi się owa potęga w Lalce, pozornie - apologii rodzącej się burżuazji.

Emancypacja polskiego mieszczaństwa? Opowieść o Wokulskim jest zwiastunem pojawienia się rodzimego kapitalizmu, ale czegoś w niej brak. Gdzie bowiem opisane są losy owego twardego kupca, gdy budował swój majątek? Dlaczego dla Prusa jego przygody w Rosji nie są warte opowiedzenia? Nieprawdopodobne przestrzenie, które musiał pokonywać, targi z ruskimi bogaczami, skala transakcji, których w Polsce nikt pewnie nie umiał sobie

7 Tamże.

8 K. Marks, F. Engels, Manifest komunistyczny, w: tychże Dzieła wybrane, t. 1, Książka i Wiedza, Warszawa 1949, s. 29. 
wyobrazić? Wódka, szampan, kawior - bo to wszystko musiało być... Jego spojrzenie na „nacmienów”, ludy niesłowiańskie, żyjące obok Rosjan. Mordwini, Tatarzy, Tadżykowie i Kazachowie... Owszem, rozumiemy to, że Sienkiewicz nie mógł opisać, jak Andrzej Kmicic Moskali podchodził, bo rosyjska cenzura tego by nie przepuściła. Ale czy nie przepuściłaby historii bogacenia się Polaka w Imperium?

Poprzez losy angielskiego kupca, zwanego po chińsku Tai Panem, James Clavell opowiada historię założenia brytyjskiej kolonii w Hongkongu. I przedstawia coś, co do dziś kształtuje wyobraźnię Anglosasów - nieprawdopodobne przestrzenie oceanów, targi z chińskimi mandarynami, sumy, którymi operowali monopoliści, kontrolujący w połowie XIX wieku praktycznie cały handel herbatą. Chińskie uczty, piratów, kurtyzany... A w tle cały czas czuje się potwora kapitału, który swoim oddechem przenika wszystkich bohaterów.

Ten potwór mało jest obecny w żyłach Wokulskiego. Tak naprawdę zabije go potwór pańskiej pychy.

Balzac, owszem, opisywał nieszczęśliwe miłości swoich bohaterów, ale wiedział, że ich uczucie podporządkowane było logice kapitalistycznej gorączki, miasta molocha. Uczucie Wokulskiego oddaje hołd imaginarium polskiej klasy hegemonicznej - ziemiaństwa. Rozpaczliwie pragnąc uznania, Wokulski próbuje się wpisać w ciasnotę i próżność tej klasy. Zapomina więc o swoim powołaniu, o tym że ostatecznie jest przede wszystkim „personifikacją kapitału" i w zgodzie z tym powinien kochać. I ginie. Ta słabość, niewiara w siebie, pozostanie dziedzictwem polskiej klasy średniej.

Można by też pytać o upamiętnienie zapewne najpotężniejszej ekspresji kapitalizmu na ziemiach polskich - żydowskiej przedsiębiorczości. Owych wielkich faktorii handlowych, operujących w imperium carów od Białegostoku do Władywostoku, współtworzących krwiobieg tego imperium. Ta historia jednak tylko częściowo wpisuje się w polską epopeję emancypacyjną, Zagłada zerwała wspólnotę losu tych dwóch ludów.

Był to zresztą skutek specyficznej „edukacji do polskości”. Ze zrozumiałych przyczyn w Polsce nie pojawiła się edukacja republikańska, podobna tej w III Republice Francuskiej, kształtująca tożsamość obywatelską. Pozbawiony niepodległości naród szlachecki wraz z bliskim mu Kościołem chciał wciągnąć w swoją nostalgiczną tożsamość uwolnionych chłopów, gdzie mu tam w głowie było obywatelstwo! Opowiada o tym znana książka Polak i katolik Michała Łuczewskiego. Atoli najprostszym sposobem obudzenia polskości w chłopach było odwołanie się do podstawowego, codziennego doświadczenia. Do 
życia w układzie zależności: chłopska chałupa, pański dwór, księży kościół, żydowska karczma. I do wskazania palcem Żyda jako obcego w tym splocie relacji, które przecież bez niego byłyby całkiem inne. Do skonstruowania przekazu, mówiącego: jesteś Polakiem, bo nie jesteś tym... Żydem. Tak o tym mówi Robert Blobaum, amerykański historyk: „Nie jest tak, że każda tożsamość narodowa jest oparta na antysemityzmie, ale każda jest do pewnego stopnia oparta na wykluczeniu Innego. Nie jest oparta na tym, kim się jest, ale kim się jest wobec Innego, czy też kim się wobec niego nie jest. Dla Czechów to mogą być Niemcy i Żydzi, dla Chorwatów - Węgrzy. Dla Polaków, bardziej niż Niemcy czy Rosjanie, byli to Żydzi"9. Skądinąd o tym epizodzie też opowiadają nam historycy „z daleka”, jak ów Blobaum.

Niewielu jest przedstawicieli współczesnej myśli, którzy penetrują obszar owej narodowej edukacji. Stąd zapewne sukces książki Łuczewskiego. Owszem, odziedziczone po odległej już myślowo epoce Syzyfowe prace opowiadają o szkole w drugiej połowie XIX wieku, kiedy była stawką unarodowienia i upolitycznienia. Ale to historia edukacji szlachty. Nawet bardziej współczesne Zmory tkwią w tym obszarze. Co więc chcemy wiedzieć o epopei instytucji edukacyjnych w autonomicznej Galicji? Co - w rusyfikowanym "priwislanskim kraju”? Albo Wielkopolsce?

U schyłku XIX wieku w Polsce tworzy się więc społeczeństwo masowe. W każdym zaborze ma to inną specyfikę. W Kongresówce najciekawsza jest industrializacja. Zupełnie inaczej przebiega to w zaborze pruskim, przede wszystkim dlatego, że państwo niemieckie - to strategia Bismarcka - programowo zaczyna włączać masy, również polskie, w politykę. W Galicji to przede wszystkim ruch ludowy, bo przemysłu nie ma, przemysł imperium Habsburgów jest w Czechach. I wreszcie - tworzenie się w dużych polskich miastach nowoczesnego społeczeństwa żydowskiego.

Społeczeństwo masowe oznacza jednak pojawienie się polityczności, ta jest bowiem warunkiem ujawnienia się podmiotowości mas. Zaczątkiem było formowanie się nowoczesnych partii politycznych, stawiających na umasowienie partycypacji; w 1892 roku odbywa się zjazd paryski PPS, w 1893 powstaje SDKPiL i zawiązuje się Liga Narodowa, w 1895 Stronnictwo Ludowe. Dramatyczne wydarzenia, zupełnie nieobecne w zbiorowej pamięci.

I nagle wydarza się wybuch 1905 roku i wejście ludu na scenę polityczną. Towarzyszy temu pojawienie się socjalistów w świadomości społecznej. Czy, poza Goraczka Agnieszki Holland, jest jakiś filmowy znak tego okresu?

9 R.E. Blobaum Rewolucja. Russian Poland 1904-1907, Cornell University Press, Ithaca 1995, s. 77. 
Czy ogromna rola polityczna mającej stosunkowo wąską bazę - ze względu na słabość industrializacji - partii socjalistycznej jest dziś jakkolwiek obecna w sferze upamiętnienia?

Przed tym okresem Kościół jawi się jako przeciwnik politycznej emancypacji ludu. Przynależy do kultury ziemiańskiej, paternalizującej, a jednocześnie kontrreformacyjnej, więc antyemancypacyjnej. Jednak rewolucja powoduje zmianę stanowiska episkopatu w kwestii polityki masowej. Na wsi rozpoczyna się „wyścig” Narodowej Demokracji budzącej, w świeżym sojuszu z Kościołem, tożsamość narodową „przez Żyda” i partii chłopskich budzących tożsamość klasową przeciw „panom”.

Te procesy wydają się zupełnie zapomniane. A przecież wówczas, podobnie jak dziś, żadna władza polityczna, żadna suwerenność i żadna kultura bazująca na przeszłości nie potrafiła sobie z nimi poradzić. Do dzisiaj, za każdym razem gdy lud się budzi, nie potrafimy sobie z tym poradzić. II Rzeczpospolita strzelała do strajków chłopskich, PRL rozjechał Solidarność „pancerami”. Dziś zaś obudzenie ludu jawi nam się w pogromowej łunie.

\section{IV}

Pierwsza wojna światowa w polskiej wyobraźni nie istnieje. A jednak ta wojna to dramat i jednocześnie zmiana fundamentalna. Dramat, jak choćby zniszczenie Kalisza przez armię niemiecką w sierpniu 1914 roku. Z siedemdziesięciu tysięcy mieszkańców pozostało pięć! Odzwierciedlone w Nocach $i$ dniach, nie weszło do kanonu wyobraźni, jak zresztą nic, co wywodzi się z Polski zachodniej. Dramatyczne zmiany kondycji chłopskiej w czasie wojny, choćby epopeja bieżeńców - dwóch milionów ludzi, przede wszystkim prawosławnych, wypędzonych ze wschodniej Polski w głąb imperium przez cofające się wojska rosyjskie ${ }^{10}$. Ogromna część nie wróciła, jak zmieniło to relacje etniczne i religijne $\mathrm{w}$ tamtych rejonach kraju? I wreszcie to, co zawsze idzie z wojną - bunty, napady na dwory i przypadki zawłaszczania pańskiej ziemi. Powtórzenie rabacji?

Rząd socjalistyczny 7 listopada w Lublinie, obietnica parcelacji, złożona przez Ignacego Daszyńskiego, zawód niemożnością jej zrealizowania. I potem rok 1920, wojna polsko-bolszewicka i ludowa reakcja na tę wojnę. Ustawa o reformie rolnej z 15 lipca 1920, w momencie załamania frontu. Czy teksty

10 A. Prymaka-Oniszk Bieżeństwo 1915. Zapomniani uchodźcy, Wydawnictwo Czarne, Wołowiec 2016. 
kultury, opowiadające o tych wydarzeniach, zauważyły w ogóle te okoliczności? Rosjanie - i Ukraińcy - mają Cichy Don, opowieść o polityzacji kozactwa w okresie rewolucji. Czy w Polsce jest - i funkcjonuje w wyobraźni zbiorowej - opowieść o zaangażowaniu roku 1920, przez niektórych uważanym za pierwszy moment, w którym lud identyfikuje się z państwem polskim? Jedyny obraz tych wydarzeń opowiedziany jest z perspektywy elity inteligencko-wojskowej, z ziemiaństwem w tle.

Uchwalenie konstytucji marcowej, mieszczańskiej, gwarantującej nienaruszalność prawa własności. Film Śmierć prezydenta Kawalerowicza - to świetne odzwierciedlenie politycznego sporu tej epoki na poziomie parlamentu. Ale gdzie zawiedzione obietnice II RP - przede wszystkim zatrzymanie reformy rolnej - i klasowa emancypacja polityczna chłopów w latach dwudziestych? Gdzie rozpad tego ruchu na podmiotowość narodową i radykalnie rewolucyjną w latach trzydziestych? Czy takie wydarzenia jak z jednej strony Przytyk, prawdziwy pogrom, z drugiej - strajki chłopskie 1937 roku, nie pokazują jakiegoś zawirowania w tej wzbierającej fali? Czy nie mają w sobie dość potencjału dramatycznego, by stanowić osnowę jakiejś opowieści?

Okres 1939-1956 i późniejsze próbowałem opisać, właśnie z perspektywy procesu emancypacyjnego, w książce Prześniona rewolucja. Najważniejsze być może w tym okresie doświadczenie Zagłady weszło do zbiorowej wyobraźni przede wszystkim przez filmy: przez Pokłosie i Idę czy W ciemności. Ale doświadczenie chłopskiej przedsiębiorczości, „biznesu”, jakim było ukrywanie Żydów, handlu żywnością, ludowego zajmowania opustoszałych miejsc w tkance społecznej - w ogóle nie zostało zobrazowane. Podobnie wojna domowa po 1945 roku i reforma rolna pod lufami NKWD. Znamienne jest to, że reforma rolna nie jest nawet opisana w pracach współczesnych historyków. Mściwe uczucia i poczucie krzywdy, nagromadzone przez wieki, ujawniające się w tej epoce, również. Może poza pozbawioną historycznego kontekstu ilustracją w Wotyniu.

\section{V}

Tożsamość zbiorowa to wiązka fantazmatów. Czyli opowieści, które podmiot sam sobie opowiada na swój własny temat, które odgrywa sam przed sobą, przegląda się w nich i ponownie przepowiada. Każda z tych opowieści musi być dramatyczna, pełna wzlotów i upadków, oddająca podmiotowy ruch, a jednocześnie moralnie spójna, dająca się wpisać w etyczną ramę. Dlatego poszczególne narracje w takiej wiązce zwykle tworzą między sobą 
napięcie - wynikają z nich różne „pouczenia”. Z tej przyczyny również wśród tych fantazmatycznych opowieści zawsze jest jedna, hegemoniczna. Dominuje ona w wyobraźni, usuwając wszystkie inne w cień, nie pozwalając im na ukształtowanie się, połączenie w znaczącą całość poszczególnych elementów, fragmentów, perspektyw i obrazów, czekających w jakimś nieświadomym „składzie".

Nienapisana epopeja, o którą się upominam, istnieje właśnie w taki sposób. Każdy z epizodów, które przytoczyłem, ma mnóstwo reprezentacji, różnorodnych udokumentowań, utkniętych gdzieś w zaciszach archiwów, filmotek, w bibliotekach i na półkach uniwersyteckich pokoików, w których rezydują "specjaliści w danej dziedzinie”. Tkwią one w mroku. Nie „spoglądają” na nasz zbiorowy podmiot, nie dają mu trajektorii, scenariusza, określającego jego ruch ku przyszłości. Przytłoczone ciężarem fantazmatycznej, utraconej Rzeczypospolitej i „zwycięstwa przez klęskę”, pozostają w statusie „strzępów, fragmentów i łachmanów", jak o materiale przyszłej historiografii pisał Walter Benjamin. Być może nawet ich ilość tworzy sytuację, którą można by przyrównać do roztworu przesyconego; wystarczyłoby jakieś jądro krystalizacji, by nadać pamięci zbiorowej jakąś nową strukturę, by wszystkie te elementy znalazły artykulację w znaczącej całości... Ale nie, to wszystko się nie zdarzy, póki dominuje fantazmat męczeński, póki nie zostanie dokończona żmudna praca nad dekonstrukcją jego hegemonicznej pozycji.

Równolegle trzeba jednak rekonstruować jednak „nienapisaną epopeję". I nie chodzi o to, żeby dokładnie i szczegółowo omówić wszystkie etapy tego procesu, nawet nie o to, by pokazać dramaturgię, wagę każdego z nich z osobna. Chodzi o strumień, wielki nurt historii, która w ten właśnie sposób dokonała tego, co w ciągu ostatnich stu pięćdziesięciu lat było w Polsce najważniejsze - emancypacji, dorastania mas do wolności - a czego pamięć została całkowicie wyparta. 


\section{Abstract}

\section{Andrzej Leder}

INSTITUTE OF PHILOSOPHY AND SOCIOLOGY OFTHE POLISH ACADEMY OF SCIENCES

The Unwritten Epos. A Few Remarks on a Forgotten Liberation

Leder examines the absence, in Polish culture, of a narrative on the history of the emancipation of the Polish people. He begins by outlining the conditions that such a narrative ought to fulfil to influence the self-awareness and self-representation of the Polish collective subject. Most importantly, a narrative ought to be complex and powerful enough to affect collective phantasms. Leder points out that the dominant martyrological narrative makes it impossible for an emancipatory narrative to emerge. Next, he discusses the successive stages that such a narrative ought to represent. He explores the first generations who lived in freedom, the Polish elites' rampart aversion to emancipation, as well as the conflicts that marked the history of the Second Polish Republic, the war and the Communist revolution. Leder concludes that the point is not to discuss all stages of this process in detail, nor is it to shed light on the dramaturgy or weight of each one in particular. The point is rather to understand the great historical trend that has led to Poland's most important achievement of the last 150 years emancipation, the attainment of the maturity requisite for freedom - even as the memory of that process is completely repressed.

\section{Keywords}

epos, emancipation, Polish culture, appropriation, industrialisation, mass politics, signifier, phantasm 